\title{
The Chemopreventive Efficacy of Vandetanib, a Multikinase Inhibitor, in a Primary Respiratory Tract Epithelial Cell Transformation Model
}

\author{
Sheela Sharma ${ }^{1, *}$, Min-Xu Zou ${ }^{1}$ and Vernon E Steele ${ }^{2}$
}

${ }^{1}$ Center for Preclinical Safety \& Efficacy, The Hamner Institutes for Health Sciences, Research Triangle Park, NC 27709, USA

${ }^{2}$ Division of Cancer Prevention, National Cancer Institute, NIH, Bethesda, MD 20892, USA

\begin{abstract}
Targeted therapies by means of compounds that inhibit multiple target molecules represent a new perspective in the treatment and prevention of cancer. Vandetanib (Zactima ${ }^{\text {TM }}$ ) is an orally active, selective inhibitor of VEGFR-2 (vascular endothelial growth factor receptor-2) receptor tyrosine kinase that also demonstrates activity against EGFR (epidermal growth factor receptor) and RET (rearranged during transfection) tyrosine kinases. As there are indications of Vandetanib being effective in advanced NSLC patients for disease free survival, we have tested Vandetanib for efficacy in a primary rat tracheal epithelial (RTE) cell transformation model, which was originally developed for identifying potential chemopreventive agents belonging to different chemical classes/biological activity. RTE cells were treated with a tobacco-specific carcinogen, benzo[a]pyrene $(B[a] P)$ alone or with five nontoxic concentrations of Vandetanib and the resulting transformed foci at the end of 30 days were scored for inhibition of transformation. In order to understand the mechanism(s) of this inhibition, the effect on biomarkers at different stages of RTE cell transformation was also tested. The results indicated that Vandetanib at half-log concentrations ranging from $0.003-0.3 \mu \mathrm{M}$, elicited an excellent dose-related inhibition of transformation (75$93 \%$ ) compared to B [a]P group $(p=<0.0001$ ). A significant dose-dependent inhibition (39-93\%) of phosphorylated tyrosine kinase activity was observed in Vandetanib-treated groups compared to $\mathrm{B}[\mathrm{a}] \mathrm{P}$ group. There was also an approximately 2-fold induction of apoptosis at $0.3 \mu \mathrm{M}$, and it inhibited survivin, a late stage biomarker, at all concentrations by $18-28 \%$. In conclusion, the data shows that there is a very good correlation between the inhibition of $\mathrm{B}[a] \mathrm{P}$-induced transformation and corresponding inhibition of activated tyrosine kinase and other biomarkers. Based on this data, animal studies are planned to develop this drug for lung cancer prevention by administering it directly to the lungs as it was found to be very effective at lower doses compared to therapeutic doses.
\end{abstract}

Keywords: Cancer prevention; Multikinase inhibitor; Vandetanib; Epithelial cell transformation; p-tyrosine kinase

Abbreviations: $\mathrm{B}[\mathrm{a}] \mathrm{P}$ : benzo $[a]$ pyrene; BSA: Bovine Serum Albumin; EGF: Epidermal Growth Factor; BPE: Bovine Pituitary Extract; SFM: Serum Free Medium; DAB: 3'3-diaminobenzidine tetrahydrochloride; BCA: Bicinchoninic acid ; NSLC: Non-Small Lung Cancer; DCP: Division of Cancer Prevention

\section{Introduction}

Cancer is still the second-leading cause of death in the United States, with an estimated 1,529,560 people diagnosed with cancer in 2010 and nearly $36 \%$ of them succumbing to it [1]. Since many types of cancers have latency periods of 20 plus years, the ideal strategy to control and eradicate cancer is to employ chemoprevention. Since many of the human cancers have complex etiologies (e.g., lung, breast and colon cancer) with an extended dormant period, the most effective chemopreventive strategy would be to employ agents that will inhibit promotion/progression of existing mutated cells to malignancy. Targeted therapies by means of compounds that inhibit a specific target molecule represent a new perspective in the treatment of cancer. As conventional chemotherapy causes damage to normal tissues, the use of targeted drugs are much more effective as they can selectively destroy tumor cells involved in tumor progression. A class of compounds that control cell proliferation and death, such as Tyrosine Kinase Receptors (RTKs) for growth factors, are among the best targets for this type of therapeutic approach. For example, Vandetanib or Zactima ${ }^{\mathrm{TM}}$ (ZD 6474 ) is a potent orally active, selective inhibitor of VEGFR-2 receptor tyrosine kinase that also demonstrates activity against EGFR and RET tyrosine kinases [2,3]. VEGFR-2 and EGFR play central roles in tumor cell proliferation and endothelial cell-mediated angiogenesis and invasion, and their over expression within tumor cells correlates with poor prognosis in a wide range of malignancies [4,5]. Similarly, activated, mutated forms of RET receptor tyrosine kinase are responsible for multiple endocrine neoplasia type 2 (MEN2), and are considered vital for the growth and survival of medullary thyroid tumors and other types of cancers related to RET oncogene expression [6]. Further, excessive or mutated EGFR is associated with tumor cell resistance to chemotherapy and radiation treatment. Vandetanib has been shown to exert anti-angiogenic, anti-tumourigenic activity against a broad range of histologically distinct human tumor xenografts, including those of the lung, prostate, breast, colon, liver, central nervous system, and RET-dependent thyroid tumor cell growth [2,7-10]. In addition, enhanced antitumor efficacy has been reported with Vandetanib in combination with various chemotherapeutic drugs and radiotherapy in both in vitro and in vivo models including cancer cells with acquired resistance to anti-EGFR therapy (e.g., lung, colon, and ovary) [11-14].

*Corresponding author: Sheela Sharma, The Hamner Institutes for Health Sciences, Six Davis Drive, Research Triangle Park, NC 27709, USA, Tel: 919-5581266; Fax: 919-558-1300; E-mail: ssharma@thehamner.org

Received September 14, 2011; Accepted October 11, 2011; Published October 13, 2011

Citation: Sharma S, Zou MX, Steele VE (2011) The Chemopreventive Efficacy of Vandetanib, a Multikinase Inhibitor, in a Primary Respiratory Tract Epithelial Cell Transformation Model. J Cancer Sci Ther S3:001. doi:10.4172/1948-5956.S3-001

Copyright: @ 2011 Sharma S, et al. This is an open-access article distributed under the terms of the Creative Commons Attribution License, which permits unrestricted use, distribution, and reproduction in any medium, provided the original author and source are credited. 
The growth of any tissue, whether normal or malignant, is determined by the quantitative relationship between the rate of cell proliferation and the rate of cell death. A successful therapy for established cancers requires readjusting the quantitative cell kinetic relationship so that cell death exceeds cancer cell proliferation. If this negative relationship can be maintained, eradication of the cancer is possible and the patient can be cured. This theory has prompted us to select apoptosis as another useful biomarker for testing Vandetanib in the RTE cell transformation. In addition, in an earlier study, we observed apoptosis induction by chemopreventive agents in the RTE cell transformation inhibition assay [15] and the data revealed a significant correlation between inhibition in the FIA and the induction of apoptosis. Based on these observations, induction of apoptosis was investigated as another biomarker in this study.

Activation of apoptosis-related genes has been shown to be important in lung tumorigenesis. The apoptosis inhibitor survivin is absent in normal tissue; however, this novel inhibitor of the apoptosis protein (IAP) is selectively expressed in most of the human cancers [16-18], including lung adenocarcinoma [19]. It has been shown that $86 \%$ of resected human non-small cell lung carcinomas [20] and $~ 50 \%$ of small adenocarcinoma $(<2 \mathrm{~cm})$ [21] express the survivin gene as measured by RT-PCR with significant correlation to a decrease in overall patient survival. Another study has found that survivin mRNA level was elevated in $96 \%$ of lung carcinomas compared to normal lung tissue [22]. Based on these observations, survivin was used as a late stage biomarker in this study.

Rat tracheal epithelial (RTE) cells provide a relevant model for studying the effectiveness of chemopreventive agents that inhibit the neoplastic process by different mechanisms. The RTE cell focus inhibition assay (FIA), developed in our laboratory, has been shown to be sensitive to several classes of chemopreventive agents. Our laboratory has used the RTE FIA to analyze responses of a wide variety of agents tested in relation to their mechanisms of action and chemical classes. For example, analysis of data from 90 compounds revealed that antioxidants and free radical scavengers, including different isomers of retinoic acids and their derivatives, are a major mechanistic class of agents that are highly effective in the RTE transformation assay $[23,24]$. In addition, comparative chemopreventive efficacy of different forms of tea extracts, other polyphenols [25] and inducible nitric oxide synthase inhibitors [15] were identified using the same transformation system and several mechanism-based cell culture assays. In this study, we report the chemopreventive efficacy and associated mechanism(s) of Vandetanib in a tobacco-specific carcinogen $(\mathrm{B}[a] \mathrm{P})$-induced primary rat tracheal epithelial cell transformation system.

\section{Materials and Methods}

\section{Chemicals}

Vandetanib (CAS \# 443913-73-3, 99.1\% pure - (Figure 1)) was obtained from NCI-DCP chemical repository and stored at $4^{\circ} \mathrm{C}$. $\mathrm{B}[\mathrm{a}] \mathrm{P}$ (CAS \#50-32-8, 98\% pure) and the cell culture chemicals were purchased from Sigma (St. Louis, MO) and stored in dark at room temperature.

\section{Cells and media}

Rat tracheal epithelial (RTE) cells were isolated from 8- to 10-weekold male Fisher 344 rat (Charles River Labs, Kingston, NY) trachea, cultured and maintained in a modified Ham's F-12 serum free medium (SFM) as previously reported from our laboratory [26] for a week, then switched to a selection media consisting of Ham's F12 plus 5\% FBS,
$0.1 \mu \mathrm{g} / \mathrm{ml}$ hydrocortisone, $1 \mu \mathrm{g} / \mathrm{ml}$ insulin and $2.5 \mu \mathrm{g} / \mathrm{ml}$ fungizone. The Ham's F12 serum-free media supplemented with $3 \mathrm{mg} \mathrm{BSA} / \mathrm{ml}$, $0.8 \mathrm{mM}$ calcium chloride, $0.1 \mu \mathrm{g}$ cholera toxin/ml, $5 \mathrm{ng} \mathrm{EGF} / \mathrm{ml}, 80$ $\mu \mathrm{M}$ ethanolamine, $3 \mu \mathrm{g}$ fungizone $/ \mathrm{ml}, 0.1 \mu \mathrm{g}$ hydrocortisone $/ \mathrm{ml}, 10 \mu \mathrm{g}$ insulin $/ \mathrm{ml}, 50 \mu \mathrm{M}$ phosphoethanolamine, $5 \mu \mathrm{g}$ human transferrin $/ \mathrm{ml}$ and $1 \% \mathrm{BPE})$.

\section{Dose selection assays}

To select appropriate nontoxic doses for testing Vandetanib, an initial cytotoxicity test was performed as published previously [26]. Briefly, RTE cells $\left(1 \times 10^{4}\right)$ were plated in $3 \mathrm{~mL}$ of SFM into 4 sterile $60-\mathrm{mm}$ tissue culture dishes. On Day 2, they were exposed to $10 \mu \mathrm{g} / \mathrm{ml}$ $\mathrm{B}[\mathrm{a}] \mathrm{P}$ alone or with one of five concentrations of Vandetanib $(0.03,0.3$, 3,30 and $100 \mu \mathrm{M}$ ) in DMSO (not to exceed $0.2 \%$ ) or only DMSO. On Day 3, $\mathrm{B}[\alpha] \mathrm{P}$ was removed, dishes were rinsed twice with F-12 basal media and refed with SFM + Vandetanib. After 7 to 8 days, depending on colony size, the cultures were fixed in $70 \%$ ethanol and stained with $15 \%$ Giemsa and the colony-forming efficiency (CFE) determined.

\section{RTE Cell Focus Inhibition Assay (FIA)}

RTE cells were plated and treated with B[a]P as described before [27]. From the initial cytotoxicity test, a concentration of Vandetanib that reduces CFE to approximately $80 \%$ of control levels (i.e., a $20 \%$ or lower reduction compared to controls) was used as the highest concentration $(0.3 \mu \mathrm{M})$ plus four half-log dilutions $(0.003,0.01,0.03$, $0.1 \mathrm{uM}$ ) for the transformation inhibition assay. On Day 1, test dishes were exposed to $10 \mu \mathrm{g} / \mathrm{ml} \mathrm{B}[\mathrm{a}] \mathrm{P}$ plus Vandetanib or to the positive control (13-cis-retinoic acid at $1 \mathrm{nM})$. Sixteen dishes were used in each group. A set of four replicate cultures per group were scored after 7 to 8 days for CFE and analyzed for potential toxicity of test doses. The remaining dishes were re-fed weekly with a selection media containing fresh Vandetanib doses during a 30-day time period. On Day 30, the cultures were fixed, stained, and scored under a dissecting microscope. Although all colonies were scored, only Class II and III colonies, those having a cell density of $>1300$ cells $/ \mathrm{mm}^{2}$, were used for determining a test agent's effectiveness. The transformation frequency was calculated by dividing the number of Class II + Class III foci per dish by the surviving colony-forming units per dish [27]. This procedure corrects for any cytotoxicity of the chemopreventive agent.

\section{Detection of apoptosis}

Eight dishes per group were plated with freshly isolated RTE cells $\left(2 \times 10^{4}\right)$ and 24 hours after plating, the cells were treated with $10 \mu \mathrm{g} / \mathrm{ml} \mathrm{B}[a] \mathrm{P}$ only, or $\mathrm{B}[a] \mathrm{P}$ plus five half $\log$ concentrations of

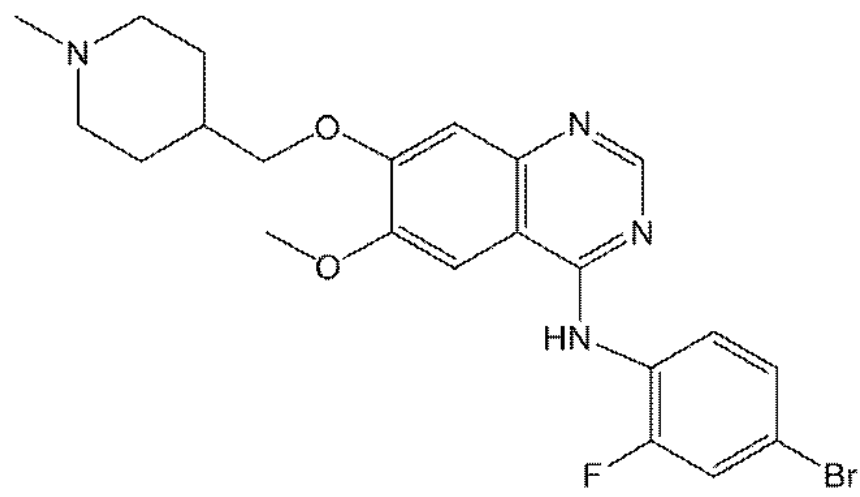

Figure 1: Chemical Structure of Vandetanib. 


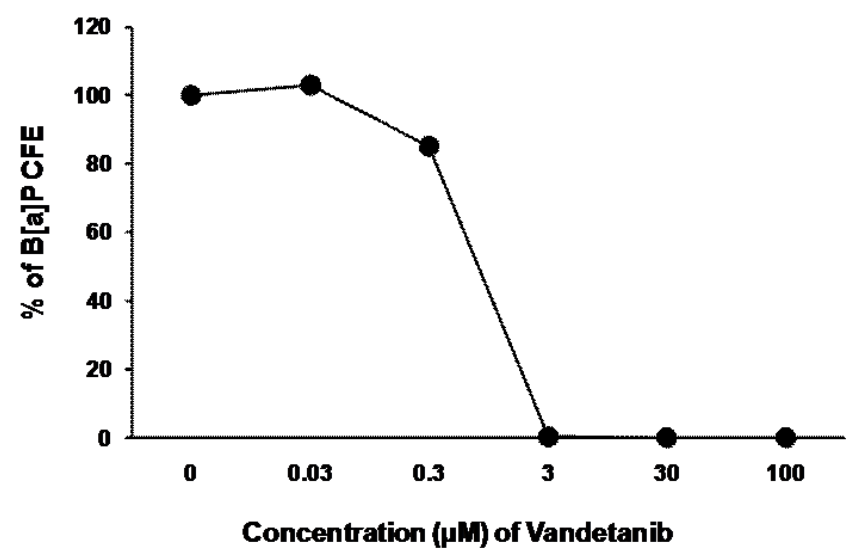

Figure 2: Dose Selection of Vandetanib in RTE Cells. Primary RTE cells were treated with Vandetanib at concentrations of $0.003,0.03,0.3,3,30$ and $100 \mu \mathrm{M}$ and the colony forming efficiency (CFE) was measured and compared to the CFE of $\mathrm{B}[\mathrm{a}] \mathrm{P}$.

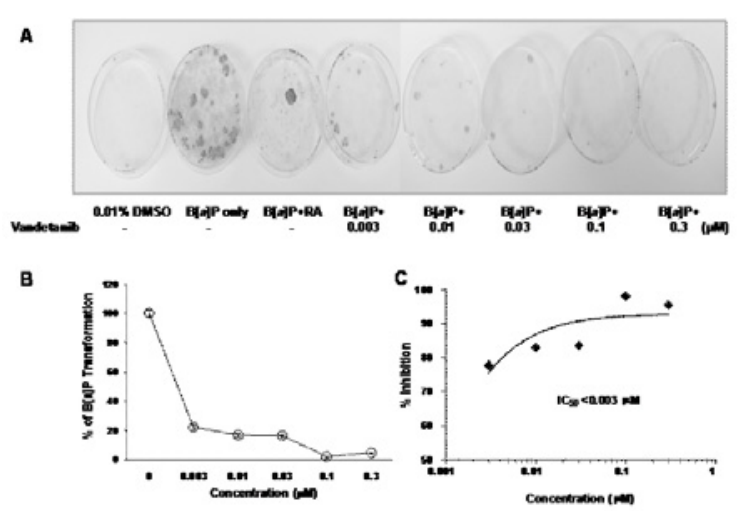

Figure 3: Efficacy of Vandetanib in the RTE Cell Transformation. Primary RTE cells were treated with $\mathrm{B}[\mathrm{a}] \mathrm{P}$ alone or with five half - log concentrations $(0.003,0.01,0.03,0.1$ and $0.3 \mu \mathrm{M})$ of Vandetanib. On day 30 , the culture dishes were fixed and stained for scoring of transformed foci (A). Transformation frequency was determined by scoring transformed foci (type II \& III) and the results are expressed as percent inhibition of transformation in $\mathrm{B}[a] \mathrm{P}+$ Vandetanib- treated versus untreated $\mathrm{B}[\mathrm{a}] \mathrm{P}$ control (B). As the lowest concentration of Vandetanib on $\mathrm{B}[\mathrm{a}] \mathrm{P}$-induced transformation showed more than $50 \%$ inhibition, the $1 C_{50}$ value is considered to be $<0.003 \mu \mathrm{M}(\mathrm{C})$.

Vandetanib ranging from $0.003-0.3 \mu \mathrm{M}$ as described for the RTE FIA . The next day, $\mathrm{B}[a] \mathrm{P}$ was removed and the cells were retreated with the test agent alone weekly and cultured until Day 21. On Day 21, the cells were harvested by scraping with cold PBS and cell culture slides were made using a Cytospin at a cell density of $1 \times 10^{5} /$ slide and fixed in $10 \%$ formalin for the TUNEL assay. TUNEL assay was performed using an ApopTag Peroxidase In Situ Apoptosis Detection kit. Cells were incubated with terminal deoxynucleotidyl transferase (TDT) in a humidity chamber for 2 hours at $37^{\circ} \mathrm{C}$ to label the free $3^{\prime}$ $\mathrm{OH}$ termini, followed by reacting with anti-digoxigenin-peroxidase for $30 \mathrm{~min}$ at room temperature. Color was then developed using freshly prepared DAB (3'3-diaminobenzidine tetrahydrochloride) substratechromogen solution and counter-stained with $0.1 \%$ methyl green. Two thousand cells/treatment were scored to determine the apoptotic index (\# apoptotic cells / total cells x 100) in $\mathrm{B}[a] \mathrm{P}$ alone or $\mathrm{B}[a] \mathrm{P}+$ test agent -treated samples. The data is expressed as fold induction of $\mathrm{B}[\mathrm{a}] \mathrm{P}$ alone group [15].

\section{Analysis of P-Tyrosine and survivin expression by western blotting}

Twenty dishes per group were plated with freshly isolated RTE cells $\left(2 \times 10^{4}\right)$ at the beginning of each experiment and treated with $10 \mu \mathrm{g} / \mathrm{ml}$ $\mathrm{B}[a] \mathrm{P}$ only, or $\mathrm{B}[a] \mathrm{P}$ plus five half $\log$ doses of Vandetanib $(0.003-0.3$ $\mathrm{uM}$ ) as described for the RTE FIA. The cells were refed once per week with media containing freshly prepared Vandetanib and cultured until Day 14 and 30 for determining phospho-tyrosine kinase and survivin expression, respectively. RTE cells from each time-point were washed two times with ice-cold PBS, then scraped in ice-cold PBS and the resulting pellet was solubilized in isotonic lysis buffer $(150 \mathrm{mM} \mathrm{NaCl}$, 0.5\% NP-40, 0.1\% SDS, 0.5\% Na deoxycholate, 25 mM Tris, $\mathrm{pH} 8.0$ ) containing $1 \mathrm{X}$ protease mixture inhibitors (Sigma P-8340). Following sonication on ice, cells were centrifuged at $15,000 \mathrm{xg}$ for $20 \mathrm{~min}$ at $4^{\circ} \mathrm{C}$ and aliquots of the cell lysate were stored at $-80^{\circ} \mathrm{C}$ after determining the protein concentration using the bicinchoninic acid (BCA) method (Pierce, Rockford, IL). Equally loaded proteins (30-50 $\mu \mathrm{g} / \mathrm{lane})$ were separated on $4-20 \%$ gradient Tris- $\mathrm{HCl}$ gels (BioRad) before transfer to PVDF membrane (BioRad). Target proteins were detected by immunoblotting with respective primary antibodies (anti-chicken survivin from Aves Labs., Tigard, Oregon; anti-mouse phosphotyrosine from Cell Signaling, Danvers, MA; anti-mouse $\beta$-actin from Sigma-Aldrich, St. Louis, MO) over night at $4^{\circ} \mathrm{C}$. Membranes were washed three times with PBS containing 0.05\% Tween 20 (PBST) prior to incubation with respective alkaline phosphatase (AP)-conjugated secondary antibodies (anti-chicken IgG-AP, anti-mouse IgG-AP from Sigma-Aldrich). After three washes in PBST, membrane protein band was visualized by using ECF substrate (GE Healthcare, Hillsborough, NC) under Typhoon-fluorescent-laser-imager-9410 variable mode imager, and then quantified by densitometry using ImageQuant 5.2 software (GE Healthcare). The data was normalized to $\beta$-actin.

\section{Results}

\section{Dose selection}

The CFE data from the one week assay of treating RTE cells with five log concentrations of Vandetanib up to $100 \mu \mathrm{M}$ indicated that Vandetanib has significant toxicity to the primary cells at concentrations of 3, 30 and $100 \mu \mathrm{M}$ (Figure 2). Therefore, a lower concentration of 0.3 $\mu \mathrm{M}$ of Vandetanib, which showed an $85 \%$ survival compared to the $\mathrm{B}[\alpha] \mathrm{P}$ only treated group, was selected as the highest dose for FIA.

\section{RTE cell focus inhibition assay}

The evaluation of Vandetanib in the RTE cell focus inhibition assay was done by scoring Class II and III foci as evidence for $\mathrm{B}[a]$ P-transformed RTE cell phenotype. The scanning the 30-day stained dishes for the number of transformed foci clearly showed a dramatic reduction of Class II and III foci formation (Figure 3A). As is shown in Figure $3 \mathrm{~B}$, the analysis of data, expressed as a percentage of $\mathrm{B}[\mathrm{a}]$ $\mathrm{P}$-induced transformation, by a one-way ANOVA, indicated that Vandetanib inhibited transformation significantly $(p=<0.0001)$ in a dose-related manner with inhibition ranging from $77-98 \%$ (at 0.003 $0.3 \mu \mathrm{M}$ ) without toxicity at any of the test concentrations. The positive control RA group also showed $71.4 \%$ inhibition of $\mathrm{B}[a] \mathrm{P}$-induced transformation (data not shown). Since the lowest concentration of $0.003 \mu \mathrm{M}$ still exhibited $77 \%$ inhibition, which is higher than $50 \%$, the $\mathrm{IC}_{50}$ value is considered to be lower than $0.003 \mu \mathrm{M}$ (Figure 3C).

\section{Effect of vandetanib on apoptosis induction}

RTE cells were treated with either $\mathrm{B}[\alpha] \mathrm{P}$ alone or with the same 


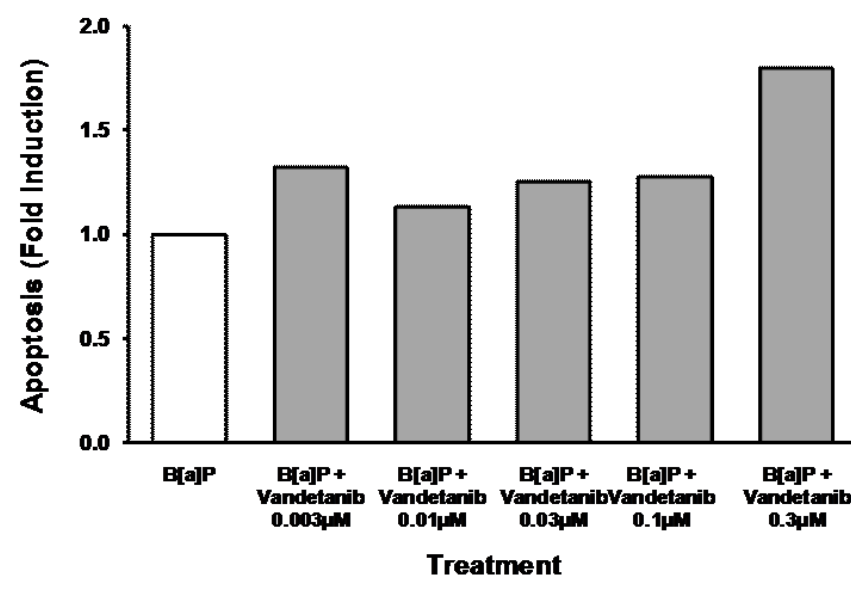

Figure 4: Effect of Vandetanib on Apoptosis in RTE Cells. Primary RTE cells were treated with $\mathrm{B}[\mathrm{a}] \mathrm{P}$ alone or with five half - log concentrations $(0.003,0.01,0.03,0.1$ and $0.3 \mu \mathrm{M})$ of Vandetanib and harvested at 21 days for measuring apoptosis by the TUNEL assay. Two thousand cells/treatment group were scored to determine the apoptotic index (number of apoptotic cells / number of total cells $\times 100$ ) and the data is expressed as fold apoptotic induction from $\mathrm{B}[\mathrm{a}] \mathrm{P}$
A

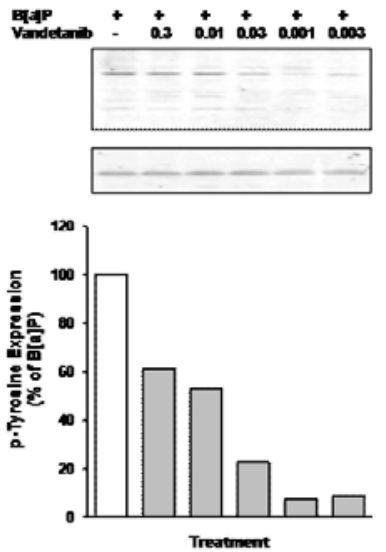

B

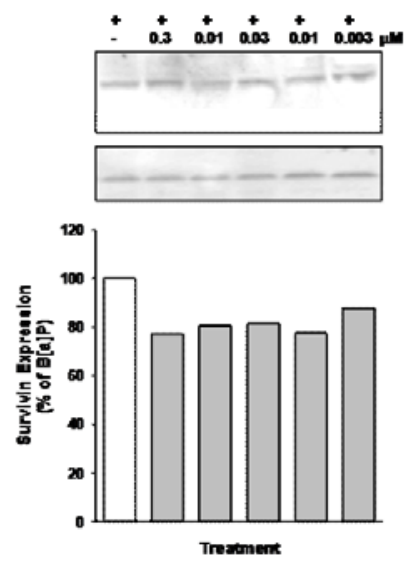

Figure 5: Effect of Vandetanib on p-Tyrosine and Survivin Expression in RTE Cells. Primary RTE cells were treated with $B[$ a $] P$ alone or with five half - $\log$ concentrations $(0.003,0.01,0.03,0.1$ and $0.3 \mu \mathrm{M})$ of Vandetanib and harvested at (A) 14 day ( $\mathrm{p}$-Tyrosine) or (B) 28 day (survivin) and processed for Western blot immunoassays. Target proteins were detected by immunoblotting with respective primary antibodies (anti-mouse p-tyrosine or anti-chicken survivin) and alkaline phosphatase-conjugated secondary antibodies (antimouse IgG-AP for p-tyrosine or anti-chicken IgG for survivin). Membrane protein bands were visualized by ECF substrate under Typhoon-fluorescentlaser-imager-9410 and quantitated after normalizing with $\beta$-actin control. The data is expressed as a percent of $\mathrm{B}[\mathrm{a}] \mathrm{P}$ control.

dose of Vandetanib that was used in the FIA assay to determine the induction of apoptosis by the TUNEL assay. The data showed a nearly 2.0 -fold induction of apoptosis at the highest concentration of $0.3 \mu \mathrm{M}$ with marginal induction at all other doses when compared to the $\mathrm{B}[a]$ P group (Figure 4).

\section{Effect of vandetanib on phospho-tyrosine kinase (p-tyrosine)} and survivin expression

As Vandetanib is a small molecule inhibitor of multiple intracellular receptor kinases, including the vascular endothelial growth factor receptor (VEGFR) -2 and epidermal growth factor receptor (EGFR), we have tested the tyrosine kinase activity of $\mathrm{B}[\mathrm{a}] \mathrm{P}$-treated RTE cells for different time points up to 4 weeks by using a p-tyrosine antibody. The data showed that there is an increase in phospho-tyrosine kinase expression from 14 to 30 days in the $\mathrm{B}[a] \mathrm{P}$ - treated group compared to the control group. As the highest p-tyrosine level was observed at 14 days (data not shown), we tested the effect of Vandetanib at the same doses as was for FIA on $\mathrm{B}[a] \mathrm{P}$ - induced p-tyrosine level at 14 days and survivin at 30 days. As is evident from the data, a significant dose-dependent inhibition of $\mathrm{B}[a] \mathrm{P}$-induced phospho-tyrosine kinase expression (39-93\%) from dose 0.003 to $0.3 \mu \mathrm{M}$ was observed (Figure $5 \mathrm{~A})$. Vandetanib also showed a dose-related inhibition ranging from $18-28 \%$ of $\mathrm{B}[a] \mathrm{P}$-induced survivin, a highly heterogeneous biomarker that appear at very late stages in cancer progression (Figure 5B).

\section{Discussion}

Vandetanib is a small-molecule inhibitor that blocks both the VEGFR and EGFR pathways, although it is more specific for the VEGFR pathway $[7,28]$. Both of these signaling pathways, involved in EGFR-dependent cell growth and VEGFR-dependent angiogenesis are validated as targets for cancer therapy in NSCLC patients [29-31]. In the Clinic, Vandetanib combined with docetaxel has shown significant prolongation of progression free survival compared with docetaxel alone in NSCLC patients [29]. Also Vandetanib monotherapy by giving a dose up to $300 \mathrm{mg} /$ day has been shown to have acceptable safety and tolerability profile and equivalent efficacy similar to erlotinib in phase III studies [30] with steady-state mean plasma drug concentration of 2.2 uM (range of 1.6-6.3 uM), however, showing side effects by consistent inhibition of both VEGFR-2 and EGFR in normal tissue $[32,33]$. Interestingly, in preclinical in vitro and in vivo studies, Vandetanib showed anti-proliferative effects by inhibiting either EGFR or VEGFR-2 signaling in endothelial cells, tumor cells and tumor xenografts [34].

Even with advances in targeted therapy of cancers, many of the newly developed targeted drugs have toxicity on chronic administration. Therefore, it is critical to demonstrate that efficacy can be achieved at low doses without any toxicity. In this study, we tested whether Vandetanib has any effect in a primary cell model of respiratory system cancer using rat tracheal epithelial (RTE) cells. Data from initial dose selection assays by assessing colony-forming efficiency (CFE) in Vandetanib-treated cells compared to untreated (solvent) control indicated that Vandetanib has severe toxicity to cultured RTE cells from 3-100 $\mu \mathrm{M}$. However at $0.3 \mu \mathrm{M}$, which showed an $85 \%$ survival was selected as the highest dose along with four other half log doses for examining the effect of Vandetanib in inhibiting a tobacco carcinogen $(\mathrm{B}[a] \mathrm{P})$-induced morphological transformation in the form of RTE cell foci in an established 30-day assay. Our data showed that Vandetanib significantly inhibited $\mathrm{B}[a] \mathrm{P}$ - induced transformation in a dose-related manner with inhibition ranging from $75-95 \%$ (at $0.003-0.3 \mu \mathrm{M}$ ) with no toxicity at any of the tested concentrations, which is significant as the next step of this study is to test it in an animal model of lung cancer mimicking former/current smokers for chemopreventive efficacy. The inhibition of $\mathrm{B}[a] \mathrm{P}$-induced transformation by $71.4 \%$ by a positive inhibitor compound, 13-cis-retinoic acid (RA) set up along with the test agent, Vandetanib, verified the integrity and validity of the RTE cell assay. Since the lowest dose of Vandetanib showed inhibition higher than $50 \%$, the $\mathrm{IC}_{50}$ value is considered to be $<0.003 \mu \mathrm{M}$. It is important to note that the $\mathrm{IC}_{50}$ value in the RTE assay is significantly lower than the reported $\mathrm{IC}_{50}$ of Vandetanib $(0.14 \mu \mathrm{M}$ and $0.22-12.2$ 
$\mu \mathrm{M}$, respectively) in literature for anti-proliferative effect on PC-9 lung cancer cells and various human cholangiocarcinoma cell lines [35]. Therefore, it appears that the primary RTE cells are much more sensitive and responsive to Vandetanib than the lung cancer or other solid tumor cell lines.

Tyrosine phosphorylation plays an important role in cellular signaling [36] and up regulated tyrosine kinase can drive malignancy and tumor formation by generating uncontrolled cell proliferation and survival signaling in cancer [37]. Taking these facts in to consideration, targeting tyrosine kinases has been clinically used for cancer therapy. Since Vandetanib is an oral anilinquinazoline that competes with ATP binding in the catalytic domain of several tyrosine kinases including the VEGFR-2 and the EGFR [38], we tested the tyrosine kinase activity of $\mathrm{B}[a] \mathrm{P}$-treated RTE cells for different time points up to 4 weeks by using a phospho-tyrosine antibody. As the highest p-tyrosine level was observed at 14 days, this time point was chosen for testing the effect of Vandetanib on $\mathrm{B}[\mathrm{a}] \mathrm{P}$ - induced $\mathrm{p}$-tyrosine level. Next we examined how Vandetanib affect phospho-tyrosine activity in $\mathrm{B}[a] \mathrm{P}$-treated RTE cells at the same doses as the FIA assay. As a significant dose-dependent inhibition of $\mathrm{B}[a] \mathrm{P}$-induced phospho-tyrosine kinase expression (39-93\%) was observed, it is very evident that there is a very good correlation between the inhibition of $\mathrm{B}[a] \mathrm{P}$-induced transformation and corresponding inhibition of activated tyrosine kinase in RTE cells mainly by inhibiting VEGFR-2 and EGFR signaling as indicated by the levels of p-tyrosine in this study. Along with this, the effect of Vandetanib in inducing apoptosis at the highest dose and consistent inhibition of survivin, a late biomarker in advanced cancers including lung cancer, at all doses is a further indication of the multi-targeted efficacy of Vandetanib. These observations prompted us to hypothesize that Vandetanib can be an effective lung cancer preventive agent at lower doses if it can be directly administered to lung via inhalation or aspiration thereby bypassing the potential systemic toxicity.

\section{Conclusion}

As Vandetanib was found to be highly effective at lower concentrations compared to the therapeutic doses with corresponding dose-dependent inhibition of tyrosine kinase activity in a primary cell (RTE cell) model of respiratory system cancer, direct administration of aerosolized drug to lung by inhalation or aspiration in animal models should yield better efficacy with least toxicity. Currently, investigation on the efficacy and mechanism(s) of Vandetanib as a chemopreventive agent in an animal model mimicking dysplasia in former/current smokers is in progress.

\section{Acknowledgement}

This study was supported by funding from $\mathrm{NCl}$ (N01-CN-43301, DCP).

\section{References}

1. Jemal A, Siegel R, Xu J, Ward E (2010) Cancer Statistics, 2010. CA Cancer J Clin 60: 277-300.

2. Hennequin LF, Stokes ESE, Thomas AP, Johnstone C, Ple PA, et al. (2002) Novel 4-anilinoquinazolines with C-7 basic side chains: Design and structure activity relationship of a series of potent, orally active, VEGF receptor tyrosine kinase inhibitors. J Med Chem 45: 1300-1312.

3. Carlomagno F, Vitagliano D, Guida T, Ciardiello F, Tortora G, et al. (2002) ZD6474, an orally available inhibitor of KDR tyrosine kinase activity, efficiently blocks oncogenic RET kinases. Cancer Res 62: 7284-7290.

4. Bergsland EK (2004) Vascular endothelial growth factor as a therapeutic target in cancer. Am J Health Syst Pharm: S4-11.

5. Lo HW, Hung MC (2006) Nuclear EGFR signalling network in cancers: Linking EGFR pathway to cell cycle progression, nitric oxide pathway and patient survival. Br J Cancer 94: 184-188.
6. Eng C, Clayton D, Schuffenecker I, Lenoir G, Cote G, et al. (1996) The relationship between specific RET proto-oncogene mutations and disease phenotype in multiple endocrine neoplasia type 2. International RET mutation consortium analysis. JAMA 276: 1575-1579.

7. Wedge SR, Ogilvie DJ, Dukes M, Kendrew J, Chester R, et al. (2002) ZD6474 inhibits vascular endothelial growth factor signaling, angiogenesis, and tumor growth following oral administration. Cancer Res 62: 4645-4655.

8. Rich JN, Sathornsumetee S, Keir ST, Kieran MW, Laforme A, et al. (2005) ZD6474, a novel tyrosine kinase inhibitor of vascular endothelial growth factor receptor and epidermal growth factor receptor, inhibits tumor growth of multiple nervous system tumors. Clin Cancer Res 11: 8145-8157.

9. Giannelli G, Azzariti A, Sgarra C, Porcelli L, Antonaci S, et al. (2006) ZD6474 inhibits proliferation and invasion of human hepatocellular carcinoma cells. Biochem Pharmacol 71: 479-485.

10. Carlomagno F and Santoro M (2004) Identification of RET kinase inhibitors as potential new treatment for sporadic and inherited thyroid cancer. J Chemother 16 Suppl 4: 49-51.

11. Shi W, Siemann DW (2005) Targeting the tumor vasculature: Enhancing antitumor efficacy through combination treatment with ZD6126 and ZD6474. In Vivo 19: 1045-1050.

12. Frederick B, Gustafson D, Bianco C, Ciardiello F, Dimery I, et al. (2006) ZD6474, an inhibitor of VEGFR and EGFR tyrosine kinase activity in combination with radiotherapy. Int J Radiat Oncol Biol.Phys 64: 33-37.

13. Ciardiello F, Bianco R, Caputo R, Caputo R, Damiano V, et al. (2004) Antitumor activity of ZD6474, a vascular endothelial growth factor receptor tyrosine kinase inhibitor, in human cancer cells with acquired resistance to antiepidermal growth factor receptor therapy. Clin Cancer Res 10: 784-793.

14. Taguchi $F$, Koh $Y$, Koizumi F, Tamura T, Saijo N, et al. (2004) Anticancer effects of ZD6474, a VEGF receptor tyrosine kinase inhibitor, in gefitinib ("Iressa")-sensitive and resistant xenograft models. Cancer Sci 95: 984-989.

15. Sharma S, Wilkinson B P, Gao P, Steele VE (2002) Differential activity of NO synthase inhibitors as chemopreventive agents in a primary rat tracheal epithelial cell transformation system. Neoplasia 4: 332-336.

16. Kawasak H, Toyoda M, Shinohara H, Okuda J, Watanabe I, et al. (2001) Expression of survivin correlates with apoptosis, proliferation, and angiogenesis during human colorectal tumorigenesis. Cancer 91: 2026-2032.

17. Das A, Tan WL, Teo J, Smith DR (2002) Expression of survivin in primary glioblastomas. J Cancer Res Clin Oncol 128: 302-306.

18. Trieb K, Lehne R, Stulnig T, Sulzbache I, Shroyer KR (2003) Survivin expression in human osteosarcoma is a marker for survival. Eur J Surg Oncol 29: 379-382.

19. Ambrosini G, Adida C, Altieri DC (1997) A novel anti-apoptosis gene, survivin, expressed in cancer and lymphoma. Nat Med 3: 917-921.

20. Monzo M, Rosell R, Felip E, Astudillo J, Sanchez JJ, et al. (1999) A nove anti-apoptosis gene: Re-expression of survivin messenger RNA as a prognosis marker in non-small-cell lung cancers. J Clin Oncol 17: 2100-2104.

21. Ikehara M, Oshita F, Kamed $Y$, Ito $H$, Ohgane N, et al. (2002) Expression of survivin correlated with vessel invasion is a marker of poor prognosis in small adenocarcinoma of the lung. Oncol Rep 9: 835-838.

22. Falleni M, Pellegrini C, Marchetti A, Oprandi B, Buttitta F, et al. (2003) Survivin gene expression in early-stage non-small cell lung cancer. J Pathol. 200: 620626 .

23. Steele VE, Kelloff GJ, Wilkinson BP, Arnold JT (1990) Inhibition of transformation in cultured rat tracheal epithelial cells by potential chemopreventive agents. Cancer Res 50: 2068-2074.

24. Arnold JT, Wilkinson BP, Sharma S, Steele VE (1995) Evaluation of chemopreventive agents in different mechanistic classes using a rat tracheal epithelial cell transformation assay. Cancer Res 55: 537-548.

25. Steele VE, Kelloff G, Balentine D, Boone CW, Mehta R, et al. (2000) Comparative chemopreventive mechanisms of green tea, black tea and selected polypheno extracts measured by in vitro bioassays. Carcinogenesis 21: 63-67.

26. Sharma S, Gao P, Steele VE (2010) Quantitative morphometry of respiratory tract epithelial cells as a tool for testing chemopreventive agent efficacy. AntiCancer Research 30: 737-742. 
Citation: Sharma S, Zou MX, Steele VE (2011) The Chemopreventive Efficacy of Vandetanib, a Multikinase Inhibitor, in a Primary Respiratory Tract Epithelial Cell Transformation Model. J Cancer Sci Ther S3:001. doi:10.4172/1948-5956.S3-001

27. Arnold JT, Wilkinson BP, Sharma S, Steele VE (1997) Chemoprevention of carcinogen-induced transformation in primary rat tracheal epithelial cells. Methods Cell Sci 19: 3-8.

28. Ciardiello F, Caputo R, Damiano V, Caputo R, Troiani T, et al. (2003) Antitumor effects of ZD6474, a small molecule vascular endothelial growth factor receptor tyrosine kinase inhibitor, with additional activity against epidermal growth factor receptor tyrosine kinase. Clin Cancer Res 9: 1546-1556.

29. Herbst RS, Sun Y, Eberhardt WE, Germonpre P, Saijo N, et al. (2010) Vandetanib plus docetaxel versus docetaxel as second-line treatment for patients with advanced non-small-cell lung cancer (ZODIAC): a double-blind, randomised, phase 3 trial. Lancet Oncol 11: 619-626.

30. Shepherd FA, Rodrigues Pereira J, Ciuleanu T, Tan EH, Hirsh V, et al. (2005) Erlotinib in previously treated non-small-cell lung cancer. N Engl J Med 353 : 123-132.

31. Sandler A, Gray R, Perry MC, Brahmer J, Schiller JH, et al. (2006) Paclitaxelcarboplatin alone or with bevacizumab for non-small-cell lung cancer. $\mathrm{N}$ Engl J Med 355: 2542-2550.

32. Morabito A, Piccirillo MC, Falasconi F, De Feo G, Del Giudice A, et al. (2009)
Vandetanib (ZD6474), a dual inhibitor of vascular endothelial growth factor receptor (VEGFR) and epidermal growth factor receptor (EGFR) tyrosine kinases: current status and future directions. Oncologist 14: 378-390.

33. Kiura K, Nakagawa K, Shinkai T, Eguchi K, Ohe Y, et al. (2008) A randomized, double-blind, phase lla dose-finding study of Vandetanib (ZD6474) in Japanese patients with non-small cell lung cancer. J Thorac Oncol 3: 386-393.

34. Brave SR, Odedra R, James NH, Smith NR, Marshall GB, et al. ( 2011) Vandetanib inhibits both VEGFR-2 and EGFR signalling at clinically relevant drug levels in preclinical models of human cancer. Int J Oncol 39: 271-278.

35. Yoshikawa D, Ojima H, Kokubu A, Ochiya T, Kasai S, et al. (2009) Vandetanib (ZD6474), an inhibitor of VEGFR and EGFR signalling, as a novel moleculartargeted therapy against cholangiocarcinoma. Br J Cancer 100: 1257-1266.

36. Schlessinger J (2000) Cell signaling by receptor tyrosine kinases. Cell 103 211-225.

37. Blume-Jensen P, Hunter T (2001) Oncogenic kinase signalling. Nature 411 355-365.

38. Flanigan J, Deshpande H, Gettinger S (2010) Current status of vandetanib (ZD6474) in the treatment of non-small cell lung cancer. Biologics 4: 237-243. 